\title{
LOS BENEFICIOS DEL DINERO ELECTRÓNICO
}

\section{AMBATO Y}

\section{TUNGURAHUA}

En las últimas semanas, se ha intensificado la publicidad sobre el uso del dinero electrónico en el país, se escuchan pronunciamientos a favor y en contra de su seguridad, aplicabilidad y sobre todo sus reservas. Siendo muy técnicos e independientes, este importante medio de pago que funciona sin dificultad y con éxito en otros países, a decir del régimen ya ha logrado que se aperturen 85.000 cuentas, siendo 3.500 de ellas de personas (naturales o jurídicas) con Registro Único de Contribuyente RUC, todas abiertas a través de Banco Central de Ecuador, marcando desde el celular *153 \#, de inmediato aceptando los términos y condiciones, luego ingresando el número de celular, finalmente respondiendo a las preguntas de validación que el mecanismo le hace y listo. De allí ya puede hacer cargas o descargas en los centros autorizados para el efecto, bancos, cooperativas de ahorro, supermercados, farmacias y restaurants que al momento llegan a unos 570 sitios de operación funcionando.

Entre los beneficios que traería el uso del dinero electrónico, están la devolución del $4 \%$ del Impuesto al Valor Agregado IVA si realiza compras pagando con este medio (Ley de Solidaridad y Corresponsabilidad Ciudadana), puede hacer pagos desde cualquier sitio (por ejemplo la comodidad del hogar) durante las 24 horas de los 365 días del año, el pago será exacto (sin redondeos), puede acceder desde un teléfono celular con cualquier tecnología, con o sin saldo o servicio de internet, es aplicable desde cualquiera de las tres operadoras de telefonía celular en el país, permite hacer retiros desde cajeros automáticos (solo autorizados), evitara dar o recibir billetes deteriorados o falsos, ahorrara tiempo porque podrá hacer pagos sin que deba físicamente trasladarse al sitio del proveedor (pagos de luz, agua, teléfono, por ejemplo) y sobre todo reducirá los niveles de riesgo personal al andar con dinero físico en los bolsillos o carteras, evitando así robos, asaltos o estafas.

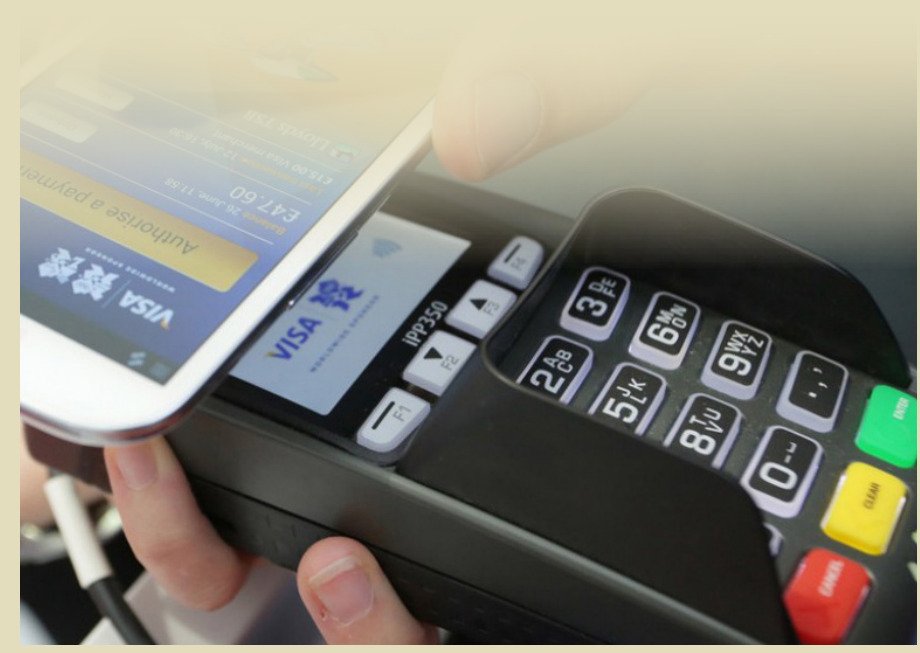

Las dudas a este moderno y tecnológico sistema de pagos, se centra en las reservas con que el dinero físico, que al hacer una carga se debe dejar en una entidad autorizada y finalmente llegaran al Banco Central del Ecuador BCE y el destino que el ex emisor le dará a ese dinero, también genera inquietud la vulnerabilidad o no, de la plataforma informática con que se manejara los cobros (crédito) y pagos (debito), para no tener sorpresas sobre los saldos reales, finalmente se manifiesta que esto implicaría ingresar en un sistema bimonetario (manejo simultáneamente de dos monedas distintas) o, la salida definitiva de la dolarización. Al respecto se puede mencionar que para evitar la desconfianza del destino final del valor de las cargas del dinero electrónico, sería adecuado dar un voto de confianza al sistema financiero privado que dicho sea de paso, tiene experiencia en manejo de plataformas informáticas de pago con las tarjetas de crédito o débito, posee la infraestructura física en todo el país para dar mayor cobertura y, su personal está capacitado para este tipo de operaciones, porque si bien el Código Orgánico Monetario y Financiero COMF en el artículo 101 reza "La moneda electrónica será puesta en circulación privativamente por el BCE, respaldado con sus activos líquidos", empero la gente quiere que sus cargas estén respaldadas a la par, es decir si se pone una carga de 10 usd, efectivamente ese valor este en reserva pagadero a la vista (de inmediato).

Respecto a que podría generarse un sistema bimonetario, de ninguna manera en Ecuador con dinero físico y electrónico ambos expresados en dólares americanos, significaría un bimonetarismo para ello debería cambiase la Constitución sobre el sistema monetario, como el COMF que en el artículo 94, segundo párrafo describe "En ningún caso el Estado podrá obligar a una persona natural o jurídica de derecho privado a recibir moneda distinta del dólar de los Estados Unidos de América". Finalmente una posible salida de la dolarización con el uso del dinero electrónico, no es factible, por el contrario el sistema fortalecería la dolarización porque le daría una mayor dinámica de compras y ventas, expresadas en dólares virtuales o físicos, pero dólares en todo los casos, el mismo COMF en el artículo 94 describe "Todas las transacciones, operaciones monetarias, financieras y sus registros contables realizados en la República del Ecuador, se expresaran en dólares de los Estados Unidos de América", por lo que una desdolarización no sería el camino. En honor a la verdad lo que sí está sucediendo es una falta de información, la difusión está siendo muy cerrada a círculos académicos y empresariales y se nota una falta de coordinación para articular las ventajas del sistema desde todas las esferas, lo que provoca nerviosismo y desconfianza en el público.

\section{Ec. Mg. Diego Proaño}

ANALISTA ECONÓMICO - ASESOR EMPRESARIAL 